\title{
IMPACT OF NATURAL AZOLLA FILICULOIDES POWDERS ON SOME PHYSIOLOGICAL, NUTRITIONAL AND BIOLOGICAL PARAMETERS OF COMMON CARP (CYPRINUS CARPIO L.)
}

\author{
SHAIMA, S. M. $.^{*}-$ BAKHAN, R. H. ${ }^{1}-$ KARZAN, F. N. ${ }^{2}-$ RABAR, M. R. ${ }^{1}-$ AVAN, A. $.{ }^{1}{ }^{1}-$ \\ NASREEN, M. A. ${ }^{3}$ \\ ${ }^{l}$ College of Agricultural Engineering Science, University of Sulaimani, Awal Road, Sulaimani, \\ Iraq \\ ${ }^{2}$ Bakrajo Technical Institute, Sulaimani Polytechnic University, Bakrajo, Sulaimani, Iraq \\ ${ }^{3}$ College of Veterinary Medicine, University of Sulaimani, Sulaimani, Iraq \\ *Corresponding author \\ e-mail: shaima.mahmood@univsul.edu.iq; phone: +964-770-139-3650
}

(Received $11^{\text {th }}$ Jan 2020; accepted $6^{\text {th }}$ May 2020)

\begin{abstract}
This study was carried out to evaluate antioxidant roles of natural Azolla filiculoides on the physiological and biological aspects of young common carp. The fish were fed 0 (control), 2.50, 5.00 and $7.5 \%$ of azolla powder for 8 weeks. There were significant differences among treatments for weight gain, specific growth rate and relative growth rate. Also, significant differences were observed $(p<0.05)$ for RBC, Hgb, MCV, PLT and WBC. On the other hand, there were no significant differences for MCH, MCHC, Granules, Lymphocyte and Monocyte. AST, total protein, globulin and albumin in fish plasma were significantly higher $(\mathrm{p}<0.05)$ for those fed with $2.50,5.00$ and $7.5 \%$ azolla than those in treatment 1 (control). The highest blood glucose value was in T1 (control) which significantly differs from that in 3 and 4. There was a significant difference in plasma cholesterol of fish fed with azolla compared to control, as well as in values of triglyceride between treatment 4 and all others. Finally, there were significant differences for Hepatosomatic index, Spleenosomatic index and condition factor. The results of this study confirmed that natural azolla $(5.00$ and $7.5 \% \mathrm{~g} \mathrm{~kg}-1$ feed) had significant effects on physiological, nutritional and biological parameters of common carp.
\end{abstract}

Keywords: fern, hematological, biochemical, antioxidant, carp

\section{Introduction}

In intensive aquaculture farm systems, feed should be high quality and rich in protein because it is important in guaranteeing higher rates of production (Narejo et al., 2010; Hardy, 1996). The feed is required to be well balanced with all the essential nutritional contents. The aquaculture feed is reasonably expensive, irregular, and in short supply for many third world countries. Major parts of fish production cost in intensive and semi-intensive aquaculture operations are in feed contents. Feed constitutes must be selected carefully since fish feed in aquaculture will play a significant role in the feeding and economic success of cultured fish. One of the high-quality sources of protein in aquaculture is fish meal and an ever more expensive contents of commercial fish culturing.

The worldwide production of fish meal was stabilized at 6 to 7 million tons in 1985, the prices of that feed component has increased (Fao, 2006). As a result, conducting research on the utilization of traditional sources of protein as components to substitute fish meal in fish diets has received rising attention by nutritionists of fish in the entire world. A number of vegetable sources have revealed to be precious to substitute fish 
meal in fish feed, either partly or fully. The utilazation of sesbania seeds (sesbania aculeata 1.), moringa leaf (moringa oleifera lamarck), mucuna seeds (mucuna pruriens 1.), duckweed (spirodela polyrrhiza 1. Schleiden), azolla lamarck, etc. in feeds for $O$. Niloticus had produced hopeful outcomes (Fasakin et al., 2001; Hossain et al., 2002; Siddhuraju and Becker, 2003; Afuang et al., 2003; Fiogbé et al., 2004). Recently using of aquatic fern azolla in feeding of fish is of great interest.

Floating freshwater, azolla is one of the important aquatic plants with high biomass and production of protein that could be used directly in fish feeding or feed components of a substitute source of protein (Radhakrishnan et al., 2014). Azolla has reached its significance in aquaculture because of higher content of crude protein (13\% to 30\%) and composition of essential amino acid (eaa) (richin lysine) than the majority of green forage crops and other aquatic macrophytes (Panigrahi et al., 2014). Despite its attractive nutritive qualities and comparative simplicity to produce in ponds, papers on utilization of azolla in aquaculture are particularly restricted. On the other hand, azolla is well recognized in a number of shellfish such as black tiger shrimp penaeus monodan (Sudaryano, 2006) and finfish such as carps (Youssouf, 2012) and nile tilapia (Maity and Patra, 2008).

These species of fish have been reported to exchange raw protein from azolla into the most excellent edible protein, therefore, decrease the production cost of diets (Datta, 2011). In addition, it is noted to contain vital constitutes which improve fish performance. Cohen et al. (2002) stated the incidence of the 3-deoxyanthocyanins which are the only known flavonoids of azolla. Furthermore, Mithraja et al. (2011) reported a variety of antioxidants like phyto-constituents such as tannins, phenolic contents and flavonoids from azolla crude extract. According to the above the objectives of the recent experiment evaluate the physiological, nutritional and biological effects of azolla in common carp.

\section{Materials and methods}

\section{Experimental fish}

The experiment was done in 8 weeks on 60 common carp C. carpio L. brought from local fish ponds in Daquq/Kirkuk/Iraq. Fish weights ranged between $60.4-62.8$ g. Fish were distributed in experimental plastic tanks with a mean initial weight of 61.7 g. Laboratory pre-acclimation (not added azolla) and feeding with commercial pellets (their percentage of ingredients and chemical composition are seen in Tables 1 and 2) were carried out for 21 days prior to the real feeding trials.

\section{Experimental system}

Twelve plastic tanks (70 1 water) were used in this trial for four treatments each with three replicates. Proper continuous aeration was added to each tank by using Chinese air compressors, hailea aco-318. Each replicate was stocked with five fish. The replicates were randomly placed to reduced differences among treatments. A daily cleaning by siphoning method was applied to remove remained feeds and feces from the system. The experimental trial represented four treatments with three replicates; each with five fish per replicate as below:

$\mathrm{t} 1$ : diet without any addition, $\mathrm{t} 2$ : adding $2.5 \%$ azolla $/ \mathrm{kg}$ diet, $\mathrm{t} 3$ : adding $5 \%$ azolla $/ \mathrm{kg}$ diet, $\mathrm{t} 4$ : adding $7.5 \%$ azolla/ $\mathrm{kg}$ diet. 
Table 1. Chemical composition of the different types of diet by NRC (1993)

\begin{tabular}{c|c|c|c|c|c}
\hline Ingredients & $\begin{array}{c}\text { Crude protein } \\
(\boldsymbol{\%})\end{array}$ & $\begin{array}{c}\text { Crude fat } \\
(\boldsymbol{\%})\end{array}$ & $\begin{array}{c}\text { Dry matter } \\
(\boldsymbol{\%})\end{array}$ & $\begin{array}{c}\text { Crude fiber } \\
(\boldsymbol{\%})\end{array}$ & $\begin{array}{c}\text { Energy } \\
(\mathbf{k c a l} / \mathbf{k g})\end{array}$ \\
\hline Animal protein concentrate & 40 & 5 & 92.9 & 2.2 & 2107 \\
Yellow corn & 8.9 & 3.6 & 89 & 2.2 & 3400 \\
Soybean meal & 48 & 1.1 & 89 & 7 & 2230 \\
Barely & 11 & 1.9 & 89 & 5.5 & 2640 \\
Wheat bran & 15.7 & 4 & 89 & 11 & 1300 \\
Azolla & 21.5 & 3.3 & 91.9 & 16.1 & 3917 \\
\hline
\end{tabular}

Table 2. Composition of experimental diet

\begin{tabular}{c|c|c|c|c}
\hline Ingredients (\%) & $\begin{array}{c}\text { Control } \\
\mathbf{1}^{\text {st }} \text { treatment }\end{array}$ & $\mathbf{2}^{\text {nd }}$ treatment & $\mathbf{3}^{\text {rd }}$ treatment & $\mathbf{4}^{\text {th }}$ treatment \\
\hline Yellow corn & $15 \%$ & $15 \%$ & $15 \%$ & $15 \%$ \\
Wheat bran & $15 \%$ & $15 \%$ & $15 \%$ & $15 \%$ \\
Animal concentrate protein & $20 \%$ & $20 \%$ & $20 \%$ & $20 \%$ \\
Barley & $15 \%$ & $15 \%$ & $15 \%$ & $15 \%$ \\
Soya bean meal 48\% & $35 \%$ & 32.5 & 30 & 27.5 \\
Azolla & 0 & 2.5 & 5 & 7.5 \\
\hline Total & \multicolumn{4}{|c}{100} \\
\hline \multicolumn{5}{c}{ Calculated chemical composition } \\
\hline Grud protein & 28.06 & & \\
\hline
\end{tabular}

\section{Diet formulation}

Experimental diets contained standard ingredients found in Sulaimani City markets, enriched with azolla. The items were mixed to obtain dough. Then, electrical mincer was used for pelleting by kenwood multi-processors. The samples were dried at room temperature for four days and crushed to obtained fine particles. Daily feeding was carried out twice at 9:00 a. m. and at 2:00 p.m. with $3 \%$ of body weight. Fish in every tank was weighed together bimonthly. The feeding levels were then recalculated according to new weights. The only modification on the fish feed was that the soybean had been replaced by azolla. The feeding trial continued for 8 weeks.

At the end of the experimental period, three fish were randomly taken from each experimental group. All fish samples were weighed and their length was measured individually. The blood samples from each fish of the different groups were collected from the caudal vein. Whole blood samples were collected in small plastic vials containing heparin and stored under cold condition (Al-koye, 2013).

The following parameters were measured: erythrocyte count (rbcs: $10^{12}$ cells/l), mean corpuscular hemoglobin (mch; pg), mean corpuscular hemoglobin concentration (mchc; g/dl), mean corpuscular volume (mcv; fl), hemoglobin (hb; g/dl) and platelet (plt; 10 $0^{9} \mathrm{cells} / \mathrm{l}$ ), differential leukocyte count $\left(10^{9}\right.$ cells/l), granulocytes $\%$, lymphocytes $\%$, monocytes $\%$. 


\section{Biochemical parameters}

Alanine aminotransferase activity (alt), aspartate aminotransferase activity (ast), total proteins, globulin $(\mathrm{g} / \mathrm{dl})$, albumin $(\mathrm{g} / \mathrm{dl})$ albumin were examined.

To determine growth and feed utilization parameters fish were weighed $(\mathrm{g})$ together for all replicate in every two weeks. Feed consumption of each replicate was read just by the obtained biomass in every two weeks.

Weight gain $(\mathrm{g} / \mathrm{fish})=$ mean of weight $(\mathrm{g})$ at the end of the experimental period weight $(\mathrm{g})$ at the beginning of the experimental period.

$$
\text { Weight gain }(\mathrm{g} / \mathrm{fish})=\mathrm{w} 2-\mathrm{w} 1
$$

where: $\mathrm{W}_{2}$ : fish weight $(\mathrm{g})$ at the end of experimental period, $\mathrm{W}_{1}$ : fish weight $(\mathrm{g})$ at the beginning of the experimental period.

Daily weight gain $(\mathrm{dwg})(\mathrm{g} / \mathrm{day})=$ weight gain / experimental period

$$
=\mathrm{w} 2-\mathrm{w}_{1} / \mathrm{t}
$$

T: time between w2 and w1 ( 84 days).

Relative growth rate $(\mathrm{rgr} \%)=$ weight gain / initial weight $\mathrm{x} 100$

$$
=\mathrm{w}_{2}-\mathrm{w}_{1} / \mathrm{w}_{1} \times 100(\text { Brown, 1957) }
$$

Specific growth rate $(\mathrm{sgr})=(\ln$ final body weight $-\ln$ initial body weight $]$

$$
\begin{aligned}
& \text { /experimental period) } \times 100=(\text { in w2 }- \text { in w1) / t }) \text { x } 100(\text { Lagler, 1956) } \\
& \text { Feed conversion ratio }(\mathrm{fcr})=\text { total feed fed }(\mathrm{g}) / \text { total wet weight gain }(\mathrm{g})(\text { Uten, 1978) } \\
& \text { Feed efficiency ratio }(\mathrm{fer})=\text { total weight gain }(\mathrm{g}) / \text { total feed fed }(\mathrm{g})(\text { Uten, 1978) }
\end{aligned}
$$

\section{Health (biological) parameters}

All fish specimens were dissected and the abdominal cavity was opened to weigh each organ alone, and they were calculated as follows.

Intestine weight index\% = intestine weight (gm)/ fish weight $(\mathrm{gm})$ x 100 (Eq.7)

Intestine length index \% = intestine length $(\mathrm{cm}) /$ fish length $(\mathrm{cm}) \times 100$ (Eq.8)

$$
\text { Condition factor }=\text { fish weight }(\mathrm{gm}) / \text { fish length }(\mathrm{cm})^{3}
$$

Gill index\% = gill weight $(\mathrm{gm}) /$ fish weight $(\mathrm{gm}) \times 100$

Fish weight index $\%$ = fish weight without viscera $(\mathrm{gm}) /$ fish weight $(\mathrm{gm}) \mathrm{x} 100$ 


\section{Water quality}

Some essential water quality parameters were measured during the experimental period. These included water dissolved oxygen $(\mathrm{mg} / \mathrm{l})$ using O2-meter (OAKTON Singapore), water temperature ${ }^{\circ} \mathrm{C}$ using thermometer ranging between zero to $100{ }^{\circ} \mathrm{C}$, water $\mathrm{pH}$ using a $\mathrm{pH}$ meter (HANNA Romania).

\section{Statistical analysis}

The trial was conducted by one way (ANOVA) with completely randomized design (crd) and general linear models (glm) procedure of xlstat 2016 version.02.28451. Duncan's test was used to compare treatment means.

\section{Results}

Physical and chemical properties of water quality during the experiment were the followings: the water temperature ranged between $\left(24-25^{\circ} \mathrm{C}\right)$ and the level of dissolved oxygen concentration in the plastic tanks was between $7-8.5 \mathrm{mg} / \mathrm{l}$ and water $\mathrm{pH}$ value was between 7 and 8.3.

There were significant differences $(\mathrm{p}<0.05)$ in weight gain among treatment 4 with other treatments, the highest values of weight gain were observed in treatment 4 . The relative growth rate, specific growth rate, food conversion ratio and food efficiency ratio of the $C$. carpio were significantly affected by feeding fish with azolla. Except food conversion ratio other parameters got the highest values with those in control (Table 3).

Table 3. Effect of replacing soyameal with azolla on growth and feed utilization parameters of young common carp (C. carpio)

\begin{tabular}{c|c|c|c|c}
\hline Parameters & $\begin{array}{c}\mathbf{t 1} \\
\text { Control }\end{array}$ & $\begin{array}{c}\mathbf{t 2} \\
\mathbf{2 . 5 \%} \text { azolla }\end{array}$ & $\begin{array}{c}\mathbf{t 3} \\
\mathbf{5 \%} \text { azolla }\end{array}$ & $\begin{array}{c}\mathbf{t 4} \\
\mathbf{7 . 5 \%} \text { azolla }\end{array}$ \\
\hline Weight gain & $9.347 \pm 0.42 \mathrm{~B}$ & $9.44 \pm 1.41 \mathrm{~B}$ & $8.867 \pm 0.26 \mathrm{~B}$ & $18.767 \pm 0.64 \mathrm{~A}$ \\
Relative growth rate & $15.271 \pm 0.56 \mathrm{~B}$ & $15.354 \pm 2.30 \mathrm{~B}$ & $14.223 \pm 0.38 \mathrm{~B}$ & $30.595 \pm 1.37 \mathrm{~A}$ \\
Specific growth rate & $4.02 \pm 0.03$ & $4.152 \pm 0.02 \mathrm{~B}$ & $4.111 \pm 0.037 \mathrm{~B}$ & $4.388 \pm 0.10 \mathrm{~A}$ \\
Food conversion ratio & $1.513 \pm 0.05 \mathrm{~A}$ & $1.579 \pm 0.25 \mathrm{~A}$ & $1.579 \pm 0.05 \mathrm{~A}$ & $0.778 \pm 0.03 \mathrm{~B}$ \\
Food efficiency ratio & $0.657 \pm 0.02 \mathrm{~B}$ & $0.667 \pm 0.09 \mathrm{~B}$ & $0.635 \pm 0.02 \mathrm{~B}$ & $1.290 \pm 0.04 \mathrm{~A}$ \\
\hline
\end{tabular}

Different letter in same rows mean significant differences $(\mathrm{p}<0.05)$

Mean values for rbc, hgb, mcv, mch, mchc, mcv, plt, wbc, granules, lymphocyte and monocyte are presented in Table 4 as mean \pm se. According to the results, there were significant differences $(\mathrm{p}<0.05)$, for $\mathrm{rbc}$, hgb, mcv, plt and wbc. However, there were no significant differences for mch, mchc, granules, lymphocyte and monocyte.

Values of ast, total protein, globulin and albumin in fish plasma were significantly higher $(\mathrm{p}<0.05)$ in treatment 2,3 and 4 than those in treatment 1 (control). While the highest activity of alt was in $\mathrm{t} 1$ (control) while in treatment 2,3 and 4 , it was $32.17 \pm 3.63$. The highest blood glucose value was in $t 1$ (control) and significantly differ with treatment 3 and 4 ( $\mathrm{p}<0.05$, Table 5).

There was a significant difference $(p<0.05)$ in plasma cholesterol levels among control with other treatments, the highest value was in control which was $(4.345 \pm 0.24)$ 
while there were insignificant differences among treatment 2, 3 and 4 . The results indicated a significant difference in values of triglyceride between treatment 4 with other treatments, triglyceride value in treatment $4(4.20 \pm 0.42$, Table 6$)$ was higher than in other treatments. Although significant differences were observed in ldl, hdl and vldl levels, the highest values of ldl and vldl were noted in treatment 1 (control) while the highest value of hdl was found in treatment 3 (Table 6).

Table 4. Effect of replacing soymeal with azolla on some haematological indices of young common carp (C. carpio)

\begin{tabular}{|c|c|c|c|c|}
\hline Parameters & $\begin{array}{c}\text { t1 } \\
\text { Control }\end{array}$ & $\begin{array}{c}\mathrm{t} 2 \\
2.5 \% \text { azolla }\end{array}$ & $\begin{array}{c}\mathrm{t3} \\
5 \% \text { azolla }\end{array}$ & $\begin{array}{c}\mathrm{t} 4 \\
7.5 \% \text { azolla }\end{array}$ \\
\hline Rbcs $\left(10^{12}\right.$ cells/l) & $1.923 \pm 0.13 \mathrm{~B}$ & $1.705 \pm 0.27 \mathrm{~B}$ & $2.033 \pm 0.13 \mathrm{~B}$ & $2.748 \pm 0.10 \mathrm{~A}$ \\
\hline $\mathrm{Hb}(\mathrm{g} / \mathrm{dl})$ & $96.25 \pm 2.01 \mathrm{C}$ & $122.00 \pm 2.41 \mathrm{~B}$ & $124.25 \pm 1.88 \mathrm{~B}$ & $137.25 \pm 3.11 \mathrm{~A}$ \\
\hline Mch (pg) & $61.50 \pm 4.64 \mathrm{~A}$ & $79.17 \pm 16.18 \mathrm{~A}$ & $63.475 \pm 2.96 \mathrm{~A}$ & $77.625 \pm 10.04 \mathrm{~A}$ \\
\hline $\operatorname{Mchc}(\mathrm{g} / \mathrm{dl})$ & $251 \pm 19.39 \mathrm{~A}$ & $378 \pm 59.14 \mathrm{~A}$ & $263.75 \pm 13.60 \mathrm{~A}$ & $331 \pm 45.33 \mathrm{~A}$ \\
\hline $\operatorname{Mcv}(f l)$ & $221.325 \pm 8.15 \mathrm{~B}$ & $232.05 \pm 7.78 \mathrm{AB}$ & $248.075 \pm 2.87 \mathrm{~A}$ & $434.35 \pm 6.28 \mathrm{AB}$ \\
\hline Plt $\left(10^{9}\right.$ cells/l) & $42 \pm 7.12 \mathrm{~B}$ & $44.25 \pm 9.44 \mathrm{~B}$ & $90 \pm 6.05 \mathrm{~A}$ & $57.25 \pm 21.33 \mathrm{AB}$ \\
\hline Wbc $\left(10^{9}\right.$ cells/ 1$)$ & $228.80 \pm 2.30 \mathrm{~B}$ & $262.475 \pm 7.55 \mathrm{~A}$ & $236.40 \pm 5.74 \mathrm{~B}$ & $245.825 \pm 8.54 \mathrm{AB}$ \\
\hline Granulocytes (\%) & $56.25 \pm 2.13 \mathrm{~A}$ & $57.45 \pm 2.17 \mathrm{~A}$ & $55.82 \pm 1.04 \mathrm{~A}$ & $59.60 \pm 1.13 \mathrm{~A}$ \\
\hline Lymphocytes (\%) & $9.925 \pm 0.83 \mathrm{~A}$ & $9.325 \pm 1.64 \mathrm{~A}$ & $10.60 \pm 0.47 \mathrm{~A}$ & $7.225 \pm 1.00 \mathrm{~A}$ \\
\hline Monocytes (\%) & $33.825 \pm 1.49 \mathrm{~A}$ & $33.225 \pm 0.94 \mathrm{~A}$ & $33.575 \pm 1.28 \mathrm{~A}$ & $33.175 \pm 0.29 \mathrm{~A}$ \\
\hline
\end{tabular}

Different letter in same rows mean significant differences $(\mathrm{p}<0.05)$

Table 5. Effect of replacing soymeal with azolla on some blood biochemical parameters of young common carp (C. carpio)

\begin{tabular}{c|c|c|c|c}
\hline Parameters & $\begin{array}{c}\mathbf{t 1} \\
\text { Control }\end{array}$ & $\begin{array}{c}\mathbf{t 2} \\
\mathbf{2 . 5 \%} \text { azolla }\end{array}$ & $\begin{array}{c}\mathbf{t 3} \\
\mathbf{5 \%} \text { azolla }\end{array}$ & $\begin{array}{c}\mathbf{t 4} \\
\mathbf{7 . 5 \%} \text { azolla }\end{array}$ \\
\hline Alanine aminotransferase activity (alt) $(\mathrm{u} / \mathrm{L})$ & $32.17 \pm 3.63 \mathrm{~A}$ & $26.17 \pm 2.91 \mathrm{AB}$ & $19.03 \pm 1.64 \mathrm{~B}$ & $21.26 \pm 1.66 \mathrm{~B}$ \\
Aspartate aminotransferase activity (ast) $(\mathrm{u} / \mathrm{L})$ & $53.275 \pm 2.26 \mathrm{~B}$ & $61.725 \pm 1.21 \mathrm{~A}$ & $65.075 \pm 0.97 \mathrm{~A}$ & $65.903 \pm 2.03 \mathrm{~A}$ \\
Total proteins (g/L) & $37.293 \pm 2.51 \mathrm{C}$ & $39.983 \pm 3.34 \mathrm{BC}$ & $47.96 \pm 1.21 \mathrm{~A}$ & $45.743 \pm 1.53 \mathrm{AB}$ \\
lood glucose (mmol/L) & $6.3 \pm 0.42 \mathrm{~A}$ & $4.785 \pm 0.23 \mathrm{AB}$ & $3.673 \pm 0.73 \mathrm{~B}$ & $4.083 \pm 0.79 \mathrm{~B}$ \\
Globulin (g/L) & $18.15 \pm 0.24 \mathrm{~A}$ & $21.48 \pm 0.11 \mathrm{~A}$ & $25.87 \pm 0.14 \mathrm{~A}$ & $22.54 \pm 0.6 \mathrm{~A}$ \\
Albumin (g/L) & $19.24 \pm 0.14 \mathrm{~A}$ & $18.45 \pm 0.71 \mathrm{~A}$ & $22.18 \pm 0.4 \mathrm{~A}$ & $23.12 \pm 0.05 \mathrm{~A}$ \\
\hline
\end{tabular}

Different letter in same rows mean significant differences $(\mathrm{p}<0.05)$.

Table 6. Effect of replacing soymeal with azolla on growth blood lipid profile of young common carp (C. carpio)

\begin{tabular}{c|c|c|c|c}
\hline Parameters & $\begin{array}{c}\mathbf{t 1} \\
\text { Control }\end{array}$ & $\begin{array}{c}\mathbf{t 2} \\
\mathbf{2 . 5 \%} \text { azolla }\end{array}$ & $\begin{array}{c}\mathbf{t 3} \\
\mathbf{5 \%} \text { azolla }\end{array}$ & $\begin{array}{c}\mathbf{t 4} \\
\mathbf{7 . 5 \%} \text { azolla }\end{array}$ \\
\hline Cholesterol (mmol/L) & $4.345 \pm 0.24 \mathrm{~A}$ & $3.085 \pm 0.16 \mathrm{~B}$ & $3.378 \pm 0.23 \mathrm{~B}$ & $3.015 \pm 0.01 \mathrm{~B}$ \\
Triglyceride (mmol/L) & $1.85 \pm 0.19 \mathrm{~B}$ & $1.875 \pm 0.17 \mathrm{~B}$ & $1.875 \pm 0.27 \mathrm{~B}$ & $4.20 \pm 0.42 \mathrm{~A}$ \\
LDL (mmol/L) & $2.98 \pm 0.68 \mathrm{~A}$ & $2.39 \pm 0.61 \mathrm{~A}$ & $0.773 \pm 0.25 \mathrm{~B}$ & $0.673 \pm 0.22 \mathrm{~B}$ \\
HDL (mmol/L) & $2.025 \pm 0.14 \mathrm{~B}$ & $1.925 \pm 0.11 \mathrm{~B}$ & $2.725 \pm 0.08 \mathrm{~A}$ & $1.950 \pm 0.32 \mathrm{~B}$ \\
VLDL (mmol/L) & $0.375 \pm 0.03 \mathrm{AB}$ & $0.375 \pm 0.03 \mathrm{AB}$ & $0.375 \pm 0.05 \mathrm{AB}$ & $0.338 \pm 0.02 \mathrm{~B}$ \\
\hline
\end{tabular}

Different letter in same rows mean significant differences $(\mathrm{p}<0.05)$. 
Significant differences $(\mathrm{p}<0.05)$ were noted in treatments in all parameters that are listed in Table 7. For hepatosomatic index, spleenosomatic index and condition factor treatment 4 had the highest values compared to other treatments. However, the highest values of gillsomatic index and meat weight index were observed in treatment 3.

Table 7. Effect of replacing soymeal with azolla on some physio-biological parameters of young common carp (C. carpio)

\begin{tabular}{c|c|c|c|c}
\hline Parameters & $\begin{array}{c}\mathbf{t 1} \\
\text { Control }\end{array}$ & $\begin{array}{c}\mathbf{t 2} \\
\mathbf{2 . 5 \%} \text { azolla }\end{array}$ & $\begin{array}{c}\mathbf{t 3} \\
\mathbf{5 \%} \text { azolla }\end{array}$ & $\begin{array}{c}\mathbf{t} 4 \\
\mathbf{7 . 5 \%} \text { azolla }\end{array}$ \\
\hline Hepatosomatic index & $1.482 \pm 0.08 \mathrm{~B}$ & $1.563 \pm 0.10 \mathrm{AB}$ & $1.920 \pm 0.16 \mathrm{~A}$ & $1.55 \pm 0.18 \mathrm{AB}$ \\
Spleenosomatic index & $0.192 \pm 0.08 \mathrm{~B}$ & $0.399 \pm 0.03 \mathrm{~A}$ & $0.221 \pm 0.04 \mathrm{AB}$ & $0.234 \pm 0.05 \mathrm{AB}$ \\
Kidneysomatic index & $0.517 \pm 0.08 \mathrm{AB}$ & $0.353 \pm 0.08 \mathrm{~B}$ & $0.680 \pm 0.11 \mathrm{~A}$ & $0.460 \pm 0.02 \mathrm{AB}$ \\
Gillsomatic index & $3.448 \pm 0.04 \mathrm{~B}$ & $3.461 \pm 0.11 \mathrm{~B}$ & $3.694 \pm 0.11 \mathrm{AB}$ & $1.950 \pm 0.32 \mathrm{~B}$ \\
Intestine weight index & $2.523 \pm 0.21 \mathrm{AB}$ & $2.528 \pm 0.20 \mathrm{AB}$ & $2.912 \pm 0.14 \mathrm{~A}$ & $2.105 \pm 0.13 \mathrm{~B}$ \\
Fish weight index & $85.799 \pm 0.97 \mathrm{AB}$ & $90.588 \pm 2.37 \mathrm{~A}$ & $86.678 \pm 0.50 \mathrm{AB}$ & $84.25 \pm 2.26 \mathrm{~B}$ \\
Meat weight index & $54.365 \pm 1.07 \mathrm{~B}$ & $55.015 \pm 0.27 \mathrm{~B}$ & $58.742 \pm 0.34 \mathrm{~A}$ & $55.036 \pm 0.52 \mathrm{~B}$ \\
Condition factor & $1.399 \pm 0.02 \mathrm{C}$ & $1.526 \pm 0.07 \mathrm{BC}$ & $1.627 \pm 0.3 \mathrm{AB}$ & $1.756 \pm 0.06 \mathrm{~A}$ \\
\hline
\end{tabular}

Different letter in same rows mean significant differences $(\mathrm{p}<0.05)$

\section{Discussion}

Azolla seems to be an excellent replacer of protein from high cost sources such as fish meal. Fish species belong to family cyprinidae stated to have diverse ranges of azolla inclusion levels in the feed. The majority of studies observed enhanced feed utilization and better growth in rohu at 10-50\% azolla inclusion level in the feed (Panigrahi et al., 2014; Datta, 2011). While orange fin labeo (Gangadhar et al., 2017), catla (Umalatha et al., 2018), silver carp and mrigal (Tuladhar, 2003), grass carp (Majhi et al., 2006), and thai silver barb (Das et al., 2018), stated to have a range between 10$25 \%$ azolla inclusion levels in the diet (Kumari et al., 2017). Same results have been observed by many researchers with some aquatic plants supplemented diet such as duck weed (Hassan and Edwards, 1992; Saini and Mathur, 2003). The reasons for the diverse addition levels may be due to the existence of $\omega-6$ fatty acids (Mohanty and Dash, 1995), nutritional value of the plants such as the gross energy content of the diet and the dietary protein (Shireman et al., 1983; Du et al., 2005) which is assimilated in a different way, depends on habits of feeding of the species (example, calta vs ruhu). Also, different enzymes in the fish gut plays a significant role in the feed digestion and utilization (Dabrowski and Glogowski, 1977).

The present study observed that the level of azolla in diets affects the growth and feed utilization efficiency of common carp. High level of azolla in diets resulted in higher growth. These trends of noted differences in growth $\mathrm{v}$ and fcr followed the results noted by Fasakin et al. (2001) and Fiogbé et al. (2004). Weight gains were $9.44 \pm 1.41$ (2.5\% azolla), $8.867 \pm 0.26$ (5\% azolla) and $18.767 \pm 0.64$ ( $7.5 \%$ azolla), (Nekoubin and Sudagar, 2013) reported that there was an increased weight for grass carp that fed with azolla was $5.04 \pm 0.53$. In addition, specific growth rates were $4.152 \pm 0.022 .5 \%$ azolla), $4.111 \pm 0.037$ (5\% azolla) and $4.388 \pm 0.10$ (7.5\% azolla) (Nekoubin and Sudagar, 2013) noted that the specific growth rate was $0.31 \pm 0.02$ in their experiment. 
Study on last research showed that biochemical parameters affect species (Catton, 1951), age (Hutton, 1967), water temperature (Hesser, 1960) and diet (Smith, 1968). In the present study different levels of azolla had significant effects on most of the hematological and biochemical parameters. Some studies seem to indicate that the type and rate of fish consumption, and its growth, are related to the chemical content or nutritive value of the plants, such as the gross energy content of the diet and the dietary protein (Shireman et al., 1983; Du et al., 2005). Nekoubin and Sudagar (2013) stated that feeding grass carp with azolla had not have any significant effect on rbc, wbc and mchc, while had significant effects on hgb, mcv, mch and mcv. Values of rbcs $\left(10^{12}\right.$ cells/l) were $1.705 \pm 0.27$ ( $2.5 \%$ azolla), $2.033 \pm 0.13$ (5\% azolla) and $2.748 \pm 0.10$ (7.5\% azolla). Nekoubin and Sudagar (2013) noted that rbc values for grass carp that fed with azolla was $1.83 \pm 0.12$. Furthermore, wbc $\left(10^{9}\right.$ cells $\left./ 1\right)$ values were $262.475 \pm 7.55$ (2.5\% azolla), $236.40 \pm 5.74$ (5\% azolla) and $245.825 \pm 8.54$ (7.5\% azolla). Nekoubin and Sudagar (2013) reported that wbc value for grass carp that fed with azolla was $7.4 \pm 1.9$.

According to the results of the present study azolla significantly affected the lipid profile (cholesterol, triglericide, ldl, hdl and vldl) of common carp, these results were confirmed by Nekoubin and Sudagar (2013) who stated that feeding grass carp with azolla significantly affected the lipid profile of the mentioned fish.

\section{Conclusion}

According to our results it was shown that natural azolla powders had significant effect on physiological parameters such as $\mathrm{RBC}, \mathrm{WBC}$ and $\mathrm{Hb}$ and lipid profile. Also, it affected biological and nutritional parameters such as weight gain, relative growth rate and specific growth rate of common carp. This suggests that azolla could be used to feed common carp in aquaculture. While this study recommends future studies on azolla as feed to common carp in real conditions such as a pond culture system.

Acknowledgements. Authors would like to express their thanks to the Animal Science Department of the College of Agricultural Science Engineering, University of Sulaimani for their help.

\section{REFERENCES}

[1] Afuang, W., Siddhuraju, P., Becker, K. (2003): Comparative nutritional evaluation of raw, methanol extracted residues and methanol extracts of moringa (Moringa oleifera Lam.) leaves on growth performance and feed utilization in Nile tilapia (Oreochromis niloticus L.). - Aquaculture Research 34: 1147-1159. https://doi.org/10.1046/j.13652109.2003.00920.x.

[2] Al-Koye, H. (2013): Effect of using Spirulina spp. instead of fishmeal on growth, blood picture and microbial load of common carp Cyprinus carpio. - MSc Thesis, College of Agriculture, University of Salahaddin, Erbil, Iraq.

[3] Brown, M. E. (1957): Experimental Studies of Growth. - In: Brown, M. E. (ed.) Physiology of Fishes. Vol. I. Academic Press, New York, pp: 361-400.

[4] Catton, W. T. (1951): Blood cell formation in certain teleost fishes. - Blood 6: 39-60.

[5] Cohen, M. F., Sakihama, Y., Takagi, Y. C., Ichiba, T., Yamasaki, H. (2002): Synergistic effect of deoxyanthocyanins from the symbiotic fern Azolla on hrm A gene induction in 
the Cyanobacterium Nostoc punctiforme. - Mol Plant Microbe Interact 15: 875-882. https://doi.org/10.1094/MPMI.2002.15.9.875.

[6] Dabrowski, K., Glogowski, J. (1977): Studies on the role of exogenous proteolytic enzymes in digestion processes in fish. - Hydrobiologia 54: 129-134. https://doi.org/10.1007/BF00034986.

[7] Das, M., Rahim, F. I., Hossain, M. A. (2018): Evaluation of fresh Azolla pinnata as a low-cost supplemental feed for Thai Silver Barb Barbonymus gonionotus. - Fishes 3: 111. https://doi.org/10.3390/fishes3010015.

[8] Datta, S. N. (2011): Culture of Azolla and its efficacy in diet of Labeo rohita. Aquaculture 310: 376-379. https://doi.org/10.1016/j.aquaculture.2010.11.008.

[9] Du, Z. Y., Liu, Y. J., Tian, J. T., Wang, Y., Liang, G. Y. (2005): Effect of dietary lipid level on growth, feed utilization and body composition by juvenile grass carp (Ctenopharyngodon idella). - Aquaculture Nutrition 11: 139-146. https://doi.org/10.1111/j.1365-2095.2004.00333.x.

[10] FAO (2006): The State of the World Fisheries and Aquaculture. - FAO, Rome.

[11] Fasakin, E. A., Balogun, A. M., Fagbenro, O. A. (2001): Evaluation of sun-dried water fern, Azolla africana, and duckweed, Spirodela polyrrhiza, in practical diets for Nile tilapia, Oreochromis niloticus, fingerlings. - Journal of Applied Aquaculture 11(4): 8392. https://doi.org/10.1300/J028v11n04_09.

[12] Fiogbé, E. D., Micha, J. C., Van Hove C. (2004): Use of a natural aquatic fern, Azolla microphylla, as a main component in food for omnivorous-phytoplanktonophagous tilapia, Oreochromis niloticus L. - Journal of Applied Ichthyology 20: 517-520. https://doi.org/10.1111/j.1439-0426.2004.00562.x.

[13] Gangadhar, B., Umalatha, H., Hegde, G., Sridhar, N. (2017): Digestibility of dry matter and nutrients from Azolla pinnata by Labeo calbasu (Hamilton, 1822) with a note on digestive enzyme activity. $\quad$ - Fish Technology 54: 94-99. https://doi.org/10.21077/ijf.2017.64.3.69091-11.

[14] Hassan, M. S., Edwards, P. (1992): Evaluation of Duckweed (Lemna perpusilla and Spirodela polyrrhiza) as feed for Nile tilapia (Oreochromis niloticus). - Aquaculture 104: 315-326. https://doi.org/10.1016/0044-8486(92)90213-5.

[15] Hardy, R. W. (1996): Alternate protein sources for salmon and trout diets. - Animal Feed Science Technology 59: 71-80. https://doi.org/10.1016/0377-8401(95)00888-8.

[16] Hesser, E. F. (1960): Method for routine fish hematology. - The Progressive Fish Culturist 22: $2164-170 . \quad$ https://doi.org/10.1577/15488659(1960)22[164:MFRFH]2.0.CO;2.

[17] Hossain, M. A., Focken, U., Becker, K. (2002): Nutritional evaluation of Dhaincha (Sesbania aculeata) seeds as dietary protein source for tilapia Oreochromis niloticus. Aquaculture Research 33: 653-662. https://doi.org/10.1046/j.1365-2109.2002.00690.x.

[18] Hutton, K. E. (1967): Characteristics of the blood of adult pinke salmon at three stages of maturity. - Fishery Bulletin of the Fish and Wild Life Service 66: 195-202.

[19] Kumari, R., Ojha, M. L., Saini, V. P., Sharma, S. K. (2017): Effect of Azolla supplementation on growth of rohu (Labeo rohita) fingerlings. - Journal of Entomology and Zoology Studies 5: 1116-1119.

[20] Lagler, F. (1956): Fresh Water Fishery Biology. - Brown Company, Dubuque, IA, pp: 131-135, 159-166.

[21] Maity, J., Patra, B. C. (2008): Effect of replacement of fishmeal by Azolla leaf mael on growth, food utilization, pancreatic protease activity and RNA/DNA ratio in the fingerlings of Labeo rohita (Ham.). - Canadian Journal of Pure and Applied Science 2: 323-333.

[22] Majhi, S. K., Das. A., Mandal, B. K. (2006): Growth performance and production of organically cultured grass carp Ctenopharyngodon idella (Val.) under mid-hill conditions of Meghalaya; North Eastern India. - Turkish Journal of Fisheries and Aquatic Sciences 6: $105-108$. 
[23] Mithraja, M. J., Antonisamy, J. M., Mahesh, M., Paul, Z. M., Jeeva, S. (2011): Phytochemical studies on Azolla pinnata R. Br., Marsilea minuta L. and Salvinia molesta Mitch. - Asian Pacific Journal Tropical Biomedicine. https://doi.org/10.1016/S22211691(11)60116-0.

[24] Mohanty, S. N., Dash, S. P. (1995): Evaluation of Azolla caroliniana for inclusion in carp diet. - Journal of Aquatic and Tropical Ecology 10: 343-353.

[25] Narejo, N. T., Dars, B. A., Achakzai, G. D. (2010): Preparation of low-cost fish feed for the culture of Labeo rohita (Hamilton) in glass aquaria. - Sindh University Research Journal (Sci. Ser.) 42: 7-10.

[26] Nekoubin, H., Sudagar, M. (2013): Effect of different types of plants (Lemna Sp., Azolla filiculoides and Alfalfa) and artificial diet (with two protein levels) on growth performance, survival rate, biochemical parameters and body composition of grass carp (Ctenopharyngodon idella). - Journal of Aquaculture Research Development 4: 167. https://doi.org/10.4172/2155-9546.1000167.

[27] Panigrahi, S., Choudhary, D., Sahoo, J. K., Das, S. S., Rath, R. K. (2014): Effect of dietary supplementation of Azolla on growth and survibility of Labeo rohita fingerlings. Asian Journal of Animal Science 9: 33-37.

[28] Radhakrishnan, S., Saravana, B. P., Seenivasan, C., Shanthi, R., Muralisankar, T. (2014): Replacement of fishmeal with Spirulina platensis, Chlorella vulgaris and Azolla pinnata on non-enzymatic and enzymatic antioxidant activities of Macrobrachium rosenbergii. The Journal of Basic \& Applied Zoology 67: 25-33. http://dx.doi.org/10.1016/j.jobaz.2013.12.003.

[29] Saini, V. P., Mathur, S. (2003): Supplementation of duckweed (Lemna minor) in the experimental diet of Labeo rohita (Ham.). - Geobios 30: 213-216.

[30] Siddhuraju, P., Becker, K. (2003): Comparative nutritional evaluation of differentially processed mucuna seeds [Mucuna pruriens (L.) DC. Var. utilis (wall exWight) Baker ex Burck)] on growth performance, feed utilization and body composition in Nile tilapia (Oreochromis niloticus L.). $\quad-$ Aquaculture Research 34: 487-500. https://doi.org/10.1046/j.1365-2109.2003.00836.x.

[31] Smith, C. E. (1968): Hematological Changes in coho salmon fed folic acid deficient diet. - Journal of the Fisheries Research Board of Canada 25: 151-156. https://doi.org/10.1139/f68-009.

[32] Shireman, J. V., Rottman, R. W., Aldridge, F. J. (1983): Consumption and growth of hybrid grass carp fed four vegetation diets and trout chow in circular tanks. - Journal of Fish Biology 22: 685-693. https://doi.org/10.1111/j.1095-8649.1983.tb04228.x.

[33] Sudaryano, A. (2006): Use of Azolla ( $c$ meal as a substitute for defatted soybean meal in diets of juvenile black tiger shrimp (Penaeus monodon). - Journal of Coastal Development 9: 145-154.

[34] Tuladhar, B. (2003): Comparative study of fish yields with plant protein sources and fish meal. - Our Nature 1: 26-29. https://doi.org/10.3126/on.v1i1.300.

[35] Umalatha, H., Gangadhar, B., Hegde, G., Sridhar, N. (2018): Digestibility of three feed ingredients by Catla catla (Hamilton 1822). - Oceanography and Fish Open Access Journal 5: 555-672. https://doi.org/10.19080/OFOAJ.2018.05.555672.

[36] Uten, F. (1978): Standard methods and terminology in finfish nutrition. - Pro. World Smp. Finfish Nutrition and Technology 11: 20-23.

[37] Youssouf, A. (2012): Water quality and sediment features in ponds with Nile tilapia (Oreochromis niloticus L.) fed Azolla. - Journal of Fisheries and Aquaculture 3: 47-51. 